\title{
The Transformation of the Municipal Social Benefit System in Hungary in the Last Decade
}

\author{
ISTVÁN HOFFMAN \& ANDREA SZATMÁRI
}

\begin{abstract}
The municipalities play a significant role in the field of means-tested social benefits. Additional income benefits are primarily provided by local governments and these autonomous bodies have responsibility for several income replacement allowances. The Hungarian municipalities have strong social powers and duties, but their role is in a permanent transformation. The strongly decentralised system established in the early 1990s has been since centralised. The result is a new model, a mixed system having evolved after 2015. The income replacement benefits have been centralised and the additional income allowances have become more decentralised. In this article, the impacts of this reform are analysed and it may be stated, that the aims of the legislators have only been partly fulfilled. The centralisation of the income replacement allowances has not significantly transformed the former accessibility, a satisfying accessibility was provided by the former, local-based model, as well. The decentralisation of the additional income benefits has widened the gap between the municipalities which have different resources. This gap is relatively significant related to the housing benefits.
\end{abstract}

Keywords: • municipal social benefits $\bullet$ means-tested social benefits - municipal social systems $\bullet$ analysis of the data on social benefits • centralisation $\bullet$ decentralisation $\bullet$ Hungary

CorResPondence AdDress: István Hoffman, Ph.D., Associate Professor, Eötvös Loránd University, Faculty of Law, Egyetem tér 1-3, 1053 Budapest, Hungary, email: Hoffman.istvan@ajk.elte.hu. Andrea Szatmári, Ph.D. Student, Eötvös Loránd University, Faculty of Law, Egyetem tér 1-3, 1053 Budapest, Hungary, email: andrea@ mobilnet.hu.

https://doi.org/10.4335/17.3.535-559(2019)

ISSN 1581-5374 Print/1855-363X Online C) 2019 Lex localis

Available online at http://journal.lex-localis.press. 
I. Hoffman \& A. Szatmári: The Transformation of the Municipal Social

Benefit System in Hungary in the Last Decade

Like other public services, the organisational framework of the municipal social system has been transformed radically in the last decades: several paradigm shifts have been carried out since the Democratic Transition in this field. We are going to review its latest significant transformation, which was completed in 2015. In order to understand these permanent changes, it is very important to analyse the former transformations of the Hungarian social benefit system. First of all, as part of this analysis, we would like to show the methods and the hypothesis of our research.

2

\section{Methods}

Our research is basically a jurisprudential analysis. First of all, we would like to analyse the models and paradigms of the Hungarian legislation of municipal social benefits. As we mentioned in the introduction, the Hungarian system has been changed several times since the Democratic Transition. Therefore, these regulations and policies of the different model should also be examined. The changes and challenges of the Hungarian welfare system have also been related to the international environment. Despite the fact that social benefits are basically not elements of the common market of the European Union, the Hungarian regulation has been partly influenced by its supranational legislation. The transformation of this system has been strongly impacted by the international examples and models, as well. Therefore, the analysis of the welfare models and the foreign patterns are indispensable to understand the recent Hungarian regulation.

In order to analyse the regulation of the municipal social benefit system, it is important to examine the policy of the reform, as well. As we will mention in the hypothesis of the article, the transformation of the system had clearly defined goals. We would also like to examine the fulfilment of these goals, therefore firstly, we will compare the distribution and variance among counties of the most significant income replacement benefit (employment substitution support - ESS) where the evaluation process of eligibility criteria has been transferred to the national agencies from the municipalities since March 2015, based upon the official statistical data before and after the amendments. Secondly, we will compare the municipal benefits in relation to which the regulation was significantly changed in March while remaining under the competence of the municipalities.

In the first case, our analysis is based upon the official statistical data of National Employment Agency relating to the number of persons registered as job seekers and to the recipients of ESS in February of 2015 and 2017. In order to avoid the impact of differences in job opportunities among territorial units (county, district, local municipalities), we will use the ratio of the number of recipients of benefits per the number of registered job seekers as an indicator of accessibility of the benefits. 
In the second case, our analysis is based upon the data available in the discharges of 3053 local municipal authorities of the years 2015, 2016 and 2017 relating to the expenditure on the benefits provided by (or through the budgets of) the local governments.

While the methods of our research are basically jurisprudential, the historical and the comparative approach and the statistical methods are also applied. First of all, we would like to give an overview of the major welfare models and their impacts on the municipal social benefit system.

\section{$3 \quad$ Main models of the welfare systems and their impact on the municipal social benefit system}

The municipal social benefit system is strongly influenced by the welfare model of the given country. Therefore, we would like to analyse the major welfare models and the role of the municipal benefits in these models. The classification of this international overview is based on the research of Gøsta Esping-Andersen (EspingAndersen, 2002: 13-17).

\subsection{The impact of the welfare system on the municipal social benefits}

\subsubsection{The Nordic welfare model and the municipal social benefits}

In this model, the role of the central government is a major one (Esping-Andersen, 2002: 15-17), because the model is based on universal benefits (Rauch, 2008: 268). Esping-Andersen states that the Nordic (Scandinavian) model is expensive from the point of view of government revenue and expenditure, but the costs of this model are not significantly higher in the system-wide accounting model.

The welfare systems of the Scandinavian countries (Sweden, Denmark, Norway, Finland, Iceland) and Belgium belong to the Nordic (Scandinavian) model according to Esping-Andersen. Local governments have an important role in the social care sector because of the wide range of services, but the role of the municipal benefit system is a limited one, because of the universal benefits which are provided by the agencies of the central government (Lehto, Moss \& Rostgaard, 1999: 124).

\subsubsection{The "liberal" welfare model}

The Anglo-Saxon countries belong to the "liberal" welfare model in EspingAndersen's categorisation. The market solutions are preferred in these countries. The role of public administration - except the health care system - is residual and is limited to the benefits for persons in need. Esping-Andersen declares that although the liberal welfare governments spend much less on welfare, the price is paid by the private sector (Esping-Andersen, 2002: 16-17). In this model, means- 
testing has a crucial role in the social policy of local governments. In the AngloSaxon countries, the local government system is primarily responsible for the social benefits for the persons in need. Although the new, integrated unemployment agencies of central governments (for example the Jobcentre+ network in the United Kingdom) have an important role, the majority of these benefits are provided by the different municipalities (Hill \& Irving, 2009: 77).

\subsubsection{The continental European (Latin-German) model}

The continental model is based on the partial survival of family welfare responsibility. This system focuses on the main breadwinner's social security and the familiar nature of the model is further emphasised by the dominance of social insurance, which offers an effective protection for people with a lifelong stable job (Esping-Andersen 2002: 17 and Palier and Marin 2008: 2-3).

In continental states the means-tested social benefits are "last resorts" for those people, who have not obtained any supplies in the wide range of social insurance services; therefore, their role is only complementary. It could be generally highlighted in each state following the continental model, that the municipalities have a prominent role in the means-tested, complementary social services (Waltermann, 2011: 221-221).

\subsubsection{Some Thoughts on the welfare systems of the Post-Socialist States}

The model of the Post-Socialist states could be also interpreted as one of the subtypes of the continental (Latin-German) one. These states - especially the successor states of the former Austro-Hungarian Empire - had a significant and differentiated care system - in essence a Bismarckian type social insurance model. In the socialist period this support system was further expanded. The financing problems of the 1970s eventually led to the collapse of the socialist politicaleconomy system in 1989/90, which smashed the public services system as well (Kornai, 1992: 564-564).

The newly forming democratic regimes faced new social problems that are unprocessed both publicly and individually to the present day (Hörschelmann 2002: 219-222). The most important problem was the termination of the former fullemployment. The bankruptcy of the former state-owned enterprises and agricultural cooperatives generated job losses and mass unemployment. These states have constructed various ad hoc unemployment supply systems, which have not been able to give strategic, long-term solutions. Several countries have transformed part of their social insurance systems into private, fund-based systems. In addition, the role of local governments has significantly increased in the field of social benefits and the role of means-tested benefits has been strengthened (Tausz, 2017: 316-318). 
The role of means-tested benefits is different in the various welfare systems: the Anglo-Saxon (liberal) model is based on the prominent role of these benefits but these are practically additional tools in the Continental (Bismarckian) and Nordic systems. Obviously, the role of means-tested benefits is strongly impacted by the economic situation: during economic crises the share of means-tested benefits is typically higher. The differences between the models can be shown in Table 1.

Table 1: Means-tested benefits in several European countries (in \% of the GDP) (2007-2017)

\begin{tabular}{|l|r|r|r|r|r|r|}
\hline Country & \multicolumn{1}{|c|}{$\mathbf{2 0 0 7}$} & \multicolumn{1}{c|}{$\mathbf{2 0 0 9}$} & \multicolumn{1}{c|}{$\mathbf{2 0 1 1}$} & \multicolumn{1}{c|}{$\mathbf{2 0 1 3}$} & \multicolumn{1}{c|}{$\mathbf{1 5}$} & \multicolumn{1}{c|}{$\mathbf{2 0 1 6}$} \\
\hline EU-28 & n.a. & 2,9 & 2,9 & n.a. & n. a. & 3,3 \\
\hline $\begin{array}{l}\text { Eurozone (EU- } \\
\text { 19) }\end{array}$ & 2,6 & 3,0 & 3,0 & n.a & 3,1 & 3,1 \\
\hline Sweden & 0,7 & 0,8 & 0,8 & 0,8 & 0,7 & 0,7 \\
\hline $\begin{array}{l}\text { United } \\
\text { Kingdom }\end{array}$ & 3,7 & 4,3 & 4,2 & 4,0 & 4,9 & 4,6 \\
\hline Ireland & 4,0 & 7,2 & 6,9 & 6,9 & 4,5 & 4,3 \\
\hline Germany & 3,2 & 3,5 & 3,3 & 3,4 & 3,5 & 3,7 \\
\hline Austria & 1,9 & 2,1 & 2,2 & 2,3 & 2,6 & 2,8 \\
\hline Italy & 1,5 & 1,8 & 1,6 & 1,6 & 2,2 & 2,3 \\
\hline Spain & 2,7 & 3,3 & 4,0 & 3,6 & 3,2 & 3,1 \\
\hline Hungary & 1,4 & 1,2 & 1,0 & 0,9 & 0,8 & 0,7 \\
\hline Czechia & 0,5 & 0,3 & 0,4 & 0,5 & 0,5 & 0,5 \\
\hline
\end{tabular}

Source ESPROSS

\subsection{Municipal social benefit systems - a brief international outlook}

The municipal benefit system is a multi-layered one. First of all, these benefits are mainly means-tested benefits. In this article, the concept of mean is considered as an income and wealth mean (Hoffman, 2016: 86 and Szatmári, 2018: 320-323). This mean-test is based on the lack of income and wealth, which situation could have temporary nature, when the cause of it is an extraordinary cost or expenditure or it could be a persistent condition. Therefore, several types of temporary and permanent income replacement benefits and additional income benefits have evolved (Fazekas, 2005: 292-293). The knowledge on the exact status and condition of the applicant are very important during the evaluation of eligibility criteria of the additional income benefits, therefore these allowances are provided typically by municipalities or by bodies of the municipalities (Waltermann 2011: 235-236). The income replacement benefits have a more complex regulation. Basically, the eligibility criteria of these benefits are regulated normatively, the administrative bodies do not have any or merely a very limited deliberation or discretion. Therefore, these benefits should not be grass roots. While municipalities can have important responsibilities related to these allowances, in several countries these 
income replacement benefits are provided by the agencies of the central government.

In Germany, the unemployment benefits have basically been social insurance allowances since the 1928 reform of the social insurance system. These social insurance unemployment benefits are provided by an agency of the central government, by the Federal Labour Agency (Bundesagentur für Arbeit) and its regional agencies, by the labour offices (Waltermann, 2011: 190). These agencies are not only responsible for the social insurance unemployment benefits but also for the majority of the means-tested income replacement allowances. The provision of the local additional income benefits belongs to the responsibilities of the municipalities (Waltermann, 2011: 220-221).

Similarly, the central government plays a prominent role in the provision of income replacement benefits in the United Kingdom. The Jobcentre Plus is responsible for the majority of the provision of the means-tested social benefits (Horáková et al., 2014: 192-193). The Local Social Authorities - which are the social authorities of the county governments and unitary authorities - are mainly responsible for the provision of the services of the social and childcare and for several additional income benefits (Alcock \& May, 2014: 77-79).

The municipalities have a central role in the Nordic countries. The local governments are responsible for universal benefits. The provision of the meanstested benefits belongs to the responsibilities of the municipalities, as well, but they have just limited impact on the Scandinavian welfare systems.

\section{Transformation(s) of the Hungarian municipal social benefit system}

\subsection{Municipal social benefits before the 2015 reform}

The Hungarian municipal social benefit system is strongly influenced by the model of the former Socialist state. The social insurance was the main field of the welfare system during the Communism. The need of means-tested benefits was not recognised decades long, because the existence of the poverty in the Communist Hungary was denied (Krémer, 2009: 150-151). This "taboo" was given up by the central administration in 1969, when the regular social benefit was established by the Decree No. 2/1969 (published on $4^{\text {th }}$ May) of the Minister of Health. This means-tested benefit was provided by the local councils as by the local bodies of the unified administrative system. Because of the full employment of the Socialist state, formal unemployment benefits were unknown until 1986. During the collapse of the socialist system, formal unemployment appeared, and the labour market allowance was established. The unemployment benefit and the temporary unemployment aid were established in 1989 and 1990. 
Firstly the means-tested benefit system was developed during the Democratic Transition followed by a special model in the unemployment benefit system, in 1991. A transitional system was established by the Act IV of 1991 on the Promotion of the Employment and on the Benefits of the Unemployed People. The system was based on an insurance nature model, but it was not the part of the social insurance system. These benefits were provided by the agencies of the central government.

In 1990, a decentralised, first-tier based municipal system evolved in Hungary. In the new Hungarian municipal model, a dual task system evolved: the municipal and the delegated state tasks were distinguished. The delegated state tasks were performed by given bodies of the municipalities, primarily by the municipal clerk and exceptionally by the mayor and by the officers of the mayor's office. These tasks were performed by local bodies, but they were actually the tasks of the central government and they could not be considered as local public affairs. The task performance of the delegated state tasks was strongly supervised by the agencies of the central government and the remedies against the decision within these delegated scopes were reviewed by these agencies of the central government (Hoffman, 2018: 930-931).

The municipalities play a central role in the Hungarian social benefit system. The new regulation was based on the Act III of 1993 on the Social Administration and on the Social Benefits (hereinafter: Szt). The first-tier local governments (villages, towns, county towns, the capital and its districts) were primarily responsible for the provision of the means-tested social benefits (Fazekas, 1999: 202). These tasks were defined as municipal tasks; thus, the municipalities were able to establish their social policies relatively independently. The local social policies were regulated by local decrees which were only legally supervised by the agency of the central government. The remedies against the decisions on municipal social benefits were reviewed by the courts. Thus, a very fragmented social benefit system evolved after the Democratic Transition (Hoffman \& Krémer, 2005: 42-43).

Under the regulation of the Szt, a new, municipal based model of the means tested social benefit evolved. Although the deepest social problems were partly treated by this model, it had several dysfunctional elements. Firstly, the largest problem was the status of the income replacement social benefits. The long-term unemployment was not treated by the insurance-based unemployment benefit, because its maximum disbursement period was originally 365 days (later 180 and 270 days). Thus, the long-term unemployed people were supported by a municipal benefit, which was considered as a local one, therefore, the central government had just very limited influence on this system; the local systems could be impacted only by the executive decrees of the Government and of the minister responsible for social affairs. Therefore, a fragmented municipal jurisdiction evolved in relation with this important benefit. The second largest problem was the relatively wide local regulative tasks; the common standards of the municipal benefits were just generally 
regulated by the Szt, and several important social challenges were just partly regulated by the local governments. Especially the housing benefits were neuralgic elements of the system because these benefits were introduced primarily by the larger municipalities and they were just hardly accessible in the villages (Hoffman \& Krémer, 2005: 43-45). These benefits were partly financed by the local governments' own revenues, and the state aid was limited. Therefore, the larger municipalities, which had more resources were able build a better benefit provision system, than the smaller ones. Thus, the differences between municipalities were deepened.

The main aims of the first reform of the municipal benefit system were the strengthening the accessibility of the benefits and defining the common standards of the means-tested benefits. Thus, the main income replacement social benefits were regulated in detail and normatively, and the local regulatory powers were reduced. Similarly, new, obligatory municipal benefits were introduced by the amendments of the Szt, especially in the field of housing benefits.

The second wave of the reforms were in 2005/2006. The administration of the income replacement benefits and the most important housing benefits was transformed. These benefits were interpreted by the reform laws as delegated state tasks, which were decided by the leader of the municipal (professional) administration or by the municipal clerks. Thus, the regulative powers of the municipalities became very limited and the decisions of the municipal clerks could be reviewed by the agencies of the central government. These benefits were financed primarily by the central budget: 80 and $90 \%$ of the expenditures on these benefits were of central support. This reform can be considered as a compromise: the administration of these benefits remained local, thus it was grassroots, but these local decisions could be subject to strict supervision and review of the regional agencies of the central government.

The role of the central government was strengthened by the transformation of the eligibility criteria of the income replacement benefits: the work test was introduced during the Millennium. Those persons were entitled to receive income replacement benefits (later the regular social benefit) who participated in public employment. The different types of the public employment were mainly organised or funded by the agencies of the central government. This Anglo-Saxon element of the Hungarian social benefit system was strengthened by the reforms in 2008; the formerly unified income replacement was separated, and the availability benefit was strongly linked to the public employment. The regular social benefit remained a means-tested benefit of the relatively elderly persons and the persons with altered ability to work, health damage and parents with small children (Ferge, 2017, 173).

The role of the central government was further strengthened after the transformation of the Hungarian municipal system between 2010 and 2013. First of all, the local 
regulative powers were further reduced. Municipalities were prohibited from passing local decrees with more favourable rules on these benefits (especially relating to housing benefits and public medicine service). Thus, the fragmentation of the system was reduced by this regulation. A reverse reform occurred, as well. The municipalities had the power to pass decrees in which the access to income replacement benefits could be excluded if the residential environment of the applicant was not orderly. The concept of "orderly" could be regulated by these local decrees. ${ }^{1}$

The separation of the municipal income replacement benefit was strengthened by the reforms after 2010 and the work test became a more important element of the system. The availability support was transformed into the employment substitution support. It was emphasised by the new name, that the main supply for the persons in need were the - now unified - public employment. The benefit could be provided only if the public employment were not available for these persons. The public employment were unified and transformed: it became a special transitional support between the supported employment and the social benefits (Jakab, 2013: 63-64 and Hungler, 2012: 119-121).

The system of the social authorities has been partly transformed. The reestablishment of the districts as local agencies of the central government impacted the powers of the municipal officers, as well. Several formerly delegated state tasks were considered as central government duties. Thus, decisions on the benefit of the elderly (needy) people, the normatively regulated public medicine service and carer's allowance belonged to the new responsibilities of the district offices. The municipal clerks were responsible for the main income replacement and additional income benefits. While the agencies of the central government were strengthened, the municipal clerks remained the main bodies responsible for means-tested social benefits. The role of the municipal clerks was transformed by the regulation of the Act CLXXXIX of 2011 on the Local Self-Governments of Hungary (hereinafter Mötv). Formerly the clerks could have only delegated state powers, but the Mötv allowed them to have municipal powers and duties defined by local government decrees (Nagy \& Hoffman, 2014: 283). Thus, the municipal social tasks could be provided by the clerks, but the municipal installation of powers was merely partially transformed.

The fragmentation of the municipal benefit system was strengthened by a new regulation on the unified municipal social benefit. The former funeral allowance, temporary assistance and the extraordinary child protection support were merged into one benefit. Thus, the former common standard was weakened: the municipalities have a wide regulatory task to define the exact content of this new type of benefit. 
I. Hoffman \& A. Szatmári: The Transformation of the Municipal Social

Benefit System in Hungary in the Last Decade

The municipal social benefit system was transformed several times after the Democratic Transition. Firstly, the income replacement benefits which were the main benefits for the long-term unemployed persons were centralised and the role of the central government was strengthened. The regulation on additional income benefits were centralised before 2011/12, but since the transformation of the Hungarian municipal system, this centralisation and concentration has been weakened.

\subsection{The municipal social benefit reform in 2015: diverse processes}

This system was radically transformed in 2015. The Szt was amended in 2014 but the reform act came into force in 2015.

The reform had two elements, which were based on different paradigms. Firstly, the so called "normative benefits", whose eligibility conditions were defined and regulated precisely by the Act of Parliament (by the Szt), were centralised. They lost their local nature, they were considered as state subsidies which are provided by the local agencies of the central government, by the district offices of the government offices for the counties and the capital. Therefore, the former delegated state task provision of the municipal clerks was changed to a directly centralised model. The district offices became responsible for the provision of (normative) carer's allowance, the benefit for the elderly (needy) persons, the normative public medicine services the employment substitution support and the health damage and childcare support. As a side effect, the work test has been strengthened: the relatively elderly people who could receive the former regular social benefit became eligible for the employment substitution support thus these 17000 persons became subjects of the work test (Mózer, Tausz \& Varga, 2015: 52-53). The funding of these benefits was changed, as well. Formerly, the $90 \%$ (exceptionally $80 \%$ ) of the expenditures on these benefits was funded by the central government and $10 \%$ by the own revenues of the municipalities. As a justification of the centralisation, the legislator hypothesised that the centralisation could strengthen the accessibility to these benefits. In the former system, the municipalities which had less resources could have problems to finance the $10 \%$ of these benefits, thus the accessibility could be worse if the municipality did not have enough money for the provision of the benefits.

A reverse process could be observed in the field of several additional income benefits. The former (general) housing benefit, the debt management benefit, the carer's allowance provided by local government, and the equity public medicine service were merged into the formerly merged municipal (social) benefit, which became a unified and general social benefit. The elements of the benefits (thus the supported living conditions) and the precise eligibility criteria should be defined by the local governments, by local government decrees. Thus, a wide regulatory power was provided to the municipalities, they could define new elements of the social 
benefits. The limit of their regulatory freedom was the central legislation. Thus, a diversified municipal social benefit system has evolved. Therefore, the fragmented local social policy system of the 1990s has returned.

The concept of the new model was that the main means-tested benefits were to be the "normative" allowances provided equally by the agencies of the central government, i.e. the district offices. These equally accessible benefits could have been supplemented by the municipalities, which can take into consideration the local differences. But these differences would be limited, because of the additional nature of these benefits.

As a guarantee of the funding of the municipal social benefit, the regulation of the Act C of 1990 on the Local Taxes was amended. The new section 36/A stated, that the major local tax, the local business tax should be the primary source of the municipal social benefits.

In the following, we would like to analyse the fulfilment of the aims of the legislator. Firstly, we would like to analyse the changes of the accessibility of the general, income replacement social benefits and secondly, we would like to analyse, how the new, fragmented social benefit system impacted the municipal differences and how the new municipal benefit system has been built.

\section{Empirical analysis of the transformation of the municipal social benefit system}

As the aim of this section is to reveal the effects of the amendment of the social benefit system of 2015 on the territorial differences, we should compare the data before and after the change of the regulation. Firstly, we will compare the distribution and variance of the most significant income replacement benefit where the evaluation process of eligibility criteria has been transferred to the national territorial agencies from the local governments since March 2015. Secondly, we will compare the benefits in relation to which the regulation was significantly changed in March 2015 while the duty remaining under the competence of the municipality.

\subsection{Impact of the centralisation of means-tested income replacement benefits on their accessibility}

\subsubsection{Data sources}

We used the monthly database of National Employment Agency relating to the number of recipients of the employment substitution support (ESS) and the regular social aid (RSA) per municipalities. The last month when decision on the fulfilment of the eligibility criteria was under the competence of local authorities was February 
of 2015. In order to avoid the seasonal impact, we have chosen the same month in 2017 to assess the effects of the amendment.

Since March 2015, the eligibility criteria have remained the same for the ESS, with the exception that previously municipalities had empowerment to define further eligibility criteria relating to the orderly state of the living environment of recipients. Those who previously obtained entitlement to the RSA, partially have become entitled also to the ESS (if they have accepted its conditions) or to the health damage and child care support (if they are unable to work due to certain circumstances defined by law). Beside these less significant changes, the most important transformation is the transition of competence to the district office of the national agency from the municipal authorities on the decision.

It is not possible to directly compare the data of 2015 and 2017 relating to the ESS because the number of recipients varies according to job opportunities and primarily public employment organized by the state in cooperation with municipalities. Thus, if we want to consider the impact of the amendment of the regulation on the number of recipients, we have to choose an indicator which is independent of the job opportunities. For this reason, we will compare the share of recipients of ESS in the population concerned, which is the number of registered job seekers. We will also use the data of the above-mentioned database relating to the number of registered job seekers in order to avoid the impact of regional differences in the field of job opportunities, including the public employment opportunities.

\subsubsection{Research questions}

We have two questions to answer. The first question is what the difference of the rate of recipients of ESS was among the persons registered as job seekers at national level, before and after the amendment of the regulation. The second question is whether we can detect significant differences between territorial units (counties, district, local - first-tier - municipalities), and whether these differences were wider or not in 2017 than in 2015.

\subsubsection{Results}

In February 2015, there were 175 thousand registered job seekers in Hungary whom 70 thousand persons obtained entitlement to ESS, which is 40 per cent of the whole number. The highest rate reached 43 percent while the lowest was 12.5 per cent. The share of recipients of ESS decreased to 37.4 per cent to February 2017 at national level, the range was between 41.7 and 7.2 per cent. During this period, the number of job seekers declined to 125 thousand while the number of recipients of ESS dropped to 47 thousand. 
The better accessibility is not justified according to the data. At national level, the access to this type of benefit seems to be rather more difficult. There are only four counties where the access is higher in 2017 than in 2015. The result is shown in Figure 1.

Figure 1: Number of recipents of ESS per registered job seekers in Hungarian counties 2015, $2017(\%)$

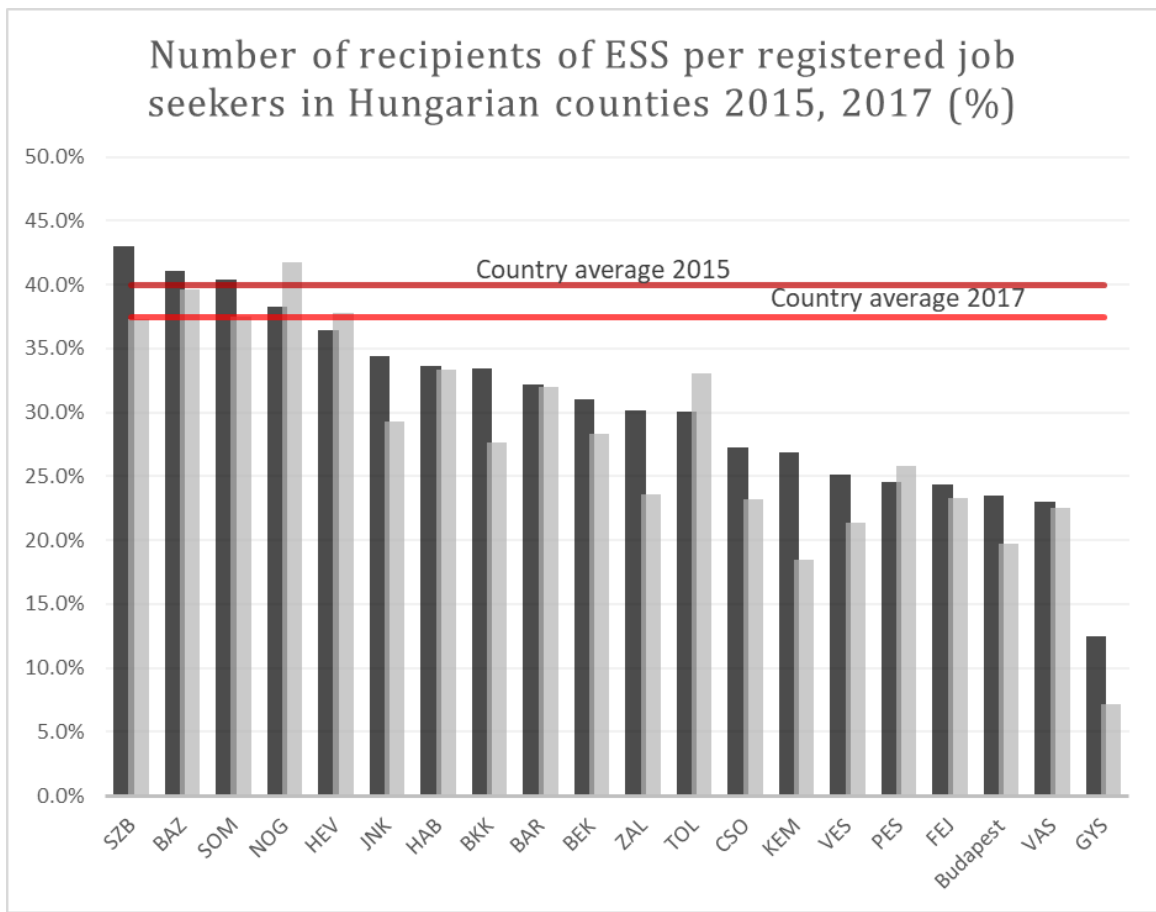

Source: Database of National Employment Agency, edited by authors

We can observe a relatively wide gap between the developed and the disadvantaged counties of the country both in 2015 and 2017. The highest level of the ESS recipients occurs in the most disadvantaged counties, and the higher share remained almost at the same level also in 2017. The significant differences can be explained by the income and wealth eligibility criteria of this benefit, and the territorial economic differences among regions and counties. The deeper reasons would require further investigation, which is not in the scope of the present article. However, it can be stated that there is no significant change in the distribution and variance between 2015 and 2017. 
I. Hoffman \& A. Szatmári: The Transformation of the Municipal Social Benefit System in Hungary in the Last Decade

\subsection{Empirical analysis of municipal benefits}

\subsubsection{Data sources}

Our analysis is based upon the discharges of the local governments of the years 2015, 2016 and 2017. The headings of the discharges are sufficiently detailed for a deeper assessment. Municipalities are obliged to send their detailed data to the Hungarian State Treasury, and we have had the opportunity to obtain these data. Table 2 shows the breakdown of "Cash benefits of the beneficiaries" at national level summarized from the discharges of more than 3000 municipalities. It is important to note that the benefits provided by the capital (Budapest) as a city are not included because the regulation of the main municipal social benefits and the provision of centrally regulated benefits are under the competence of the 22 districts. Budapest as a city has reported only 36,8 million HUF in $2015,53.8$ million HUF in 2016, and 45,7 million HUF in 2017 in the row of "Cash benefits of the beneficiaries", which sums are negligible compared to the data at national level or even that of the districts of the capital city (Budapest).

It is also an important piece of information that the database provided by the Hungarian State Treasury is incomplete regarding the years 2016 and 2017. We have data of all municipalities from 2015 , but the data of one municipality is missing from 2016, and the data of 124 municipalities are missing from 2017. For this reason, data of the missing 124 municipalities have been discarded, and the comparison will be carried out for 3053 territorial units in each year.

Furthermore, the following categories of benefits will not be analysed:

- the regulation of which was not changed in 2015;

- the benefits that have been transferred to the government agencies since 2015;

- the items which cannot be interpreted at local level or not a social support (supposedly accounting errors);

- and the benefits abolished without replacement.

Consequently, the assessment will cover the benefits that were reported in municipal discharges in 2015, and which are still existing or have equivalents in 2017 under changed conditions and financing. These benefits will be called as "benefits examined" in this study. Table 2 shows the benefits provided by local governments selected for examination, and the reason of discarding the others. 
Table 2: Benefits provided by local governments selected for examination, and the reason of discarding the others

\begin{tabular}{|c|c|c|}
\hline $\begin{array}{c}\text { Type of benefits according to the } \\
\text { headings of discharge (data of } 3053 \\
\text { municipalities) }\end{array}$ & $\begin{array}{l}\text { Selected for } \\
\text { examination } \\
(\mathrm{Y} / \mathrm{N})\end{array}$ & Reason of discarding \\
\hline $\begin{array}{l}\text { Contribution to the preschool enrollment } \\
\text { costs for low income families }\end{array}$ & $\mathrm{N}$ & $\begin{array}{l}\text { abolished without } \\
\text { replacement }\end{array}$ \\
\hline $\begin{array}{l}\text { Other child protection supports in cash } \\
\text { and in kind }\end{array}$ & $\mathrm{N}$ & $\begin{array}{l}\text { regulation has not been } \\
\text { changed }\end{array}$ \\
\hline Family benefits & \multicolumn{2}{|c|}{ summary row } \\
\hline Compensations and damages awarded & $\mathbf{N}$ & not a social support \\
\hline $\begin{array}{l}\text { Carer's allowance provided by local } \\
\text { governments }\end{array}$ & Y & \multirow{2}{*}{$\begin{array}{l}\text { merged into the municipal } \\
\text { support }\end{array}$} \\
\hline $\begin{array}{l}\text { Public medicine service provided by local } \\
\text { governments }\end{array}$ & Y & \\
\hline Entitlement for free health care & $\mathrm{N}$ & $\begin{array}{l}\text { accounting error, cannot be } \\
\text { interpreted in local level }\end{array}$ \\
\hline Sickness benefits (not contributory) & \multicolumn{2}{|c|}{ summary row } \\
\hline Employment substitution support & $\mathbf{N}$ & $\begin{array}{l}\text { competence is transferred } \\
\text { to the national agencies }\end{array}$ \\
\hline Housing costs support in cash & $\mathbf{I}$ & \multirow{4}{*}{$\begin{array}{c}\text { merged into the municipal } \\
\text { support }\end{array}$} \\
\hline Debt management service & I & \\
\hline Housing costs support in kind & I & \\
\hline $\begin{array}{l}\text { Debt management - prepaid consumption } \\
\text { meter }\end{array}$ & $\mathrm{I}$ & \\
\hline Housing supports & \multicolumn{2}{|c|}{ summary row } \\
\hline Benefits for children in foster care & $\mathbf{N}$ & \\
\hline
\end{tabular}


I. Hoffman \& A. Szatmári: The Transformation of the Municipal Social Benefit System in Hungary in the Last Decade

\begin{tabular}{|c|c|c|}
\hline $\begin{array}{c}\text { Type of benefits according to the } \\
\text { headings of discharge (data of } 3053 \\
\text { municipalities) }\end{array}$ & $\begin{array}{l}\text { Selected for } \\
\text { examination } \\
(\mathrm{Y} / \mathrm{N})\end{array}$ & Reason of discarding \\
\hline Benefits for participants in education & $\mathrm{N}$ & \multirow{2}{*}{$\begin{array}{l}\text { regulation has not been } \\
\text { changed }\end{array}$} \\
\hline Other & $\mathrm{N}$ & \\
\hline Benefits for beneficiaries of institutions & \multicolumn{2}{|c|}{ summary row } \\
\hline Regular social aid & $\mathbf{N}$ & $\begin{array}{c}\text { competence is transferred to } \\
\text { the national agencies (under } \\
\text { another name) }\end{array}$ \\
\hline Municipal aid (in cash) & I & $\begin{array}{l}\text { merged into the municipal } \\
\text { support }\end{array}$ \\
\hline Other benefits regulated by local decree & $\mathrm{I}$ & existing also in 2017 \\
\hline Regular social aid in kind & $\mathrm{N}$ & $\begin{array}{l}\text { competence is transferred to } \\
\text { the national agencies (under } \\
\text { another name) }\end{array}$ \\
\hline Municipal aid in kind & Y & $\begin{array}{l}\text { merged into the municipal } \\
\text { support }\end{array}$ \\
\hline Publicly financed funeral & $\mathrm{N}$ & $\begin{array}{l}\text { regulation has not been } \\
\text { changed }\end{array}$ \\
\hline Means-tested child protection benefits & $\mathrm{N}$ & $\begin{array}{l}\text { abolished without } \\
\text { replacement }\end{array}$ \\
\hline $\begin{array}{l}\text { Other benefits provided by local } \\
\text { government at its discretion (in cash) }\end{array}$ & I & existing also in 2017 \\
\hline $\begin{array}{l}\text { Other benefits provided by municipality } \\
\text { at its discretion (in kind) }\end{array}$ & I & existing also in 2017 \\
\hline Municipal support & I & existing also in 2017 \\
\hline
\end{tabular}


I. Hoffman \& A. Szatmári: The Transformation of the Municipal Social

Benefit System in Hungary in the Last Decade

\begin{tabular}{|l|c|c|}
\hline $\begin{array}{c}\text { Type of benefits according to the } \\
\text { headings of discharge (data of } 3053 \\
\text { municipalities) }\end{array}$ & $\begin{array}{c}\text { Selected for } \\
\text { examination } \\
\text { (Y/N) }\end{array}$ & Reason of discarding \\
\hline Health damage and child care support & $\mathrm{N}$ & $\begin{array}{c}\text { accounting error, cannot be } \\
\text { interpreted in local level }\end{array}$ \\
\hline Other & $\mathrm{I}$ & existing also in 2017 \\
\hline Other non-institutional benefits & \multicolumn{2}{|c|}{ summary row } \\
\hline Cash benefits of the beneficiaries ${ }^{2}$ & \multicolumn{2}{|c|}{ summary row } \\
\hline
\end{tabular}

Source: Registers of the Hungarian State Treasury (applied for: May 2018, received: 06 June 2018)

\subsubsection{Comparison of the benefits examined between 2015 and 2017 at national level}

Table 3: The benefits examined, data at national level

\begin{tabular}{|c|c|c|c|c|}
\hline $\begin{array}{c}\text { Social benefits examined - } \\
\text { data of } 3053 \\
\text { municipalities }\end{array}$ & $\begin{array}{c}2015 \\
(1000 \text { HUF })\end{array}$ & $\begin{array}{c}2016 \\
(1000 \mathrm{HUF})\end{array}$ & $\begin{array}{c}2017 \\
(1000 \text { HUF })\end{array}$ & $\begin{array}{l}\text { Change 2017- } \\
2015 \\
(1000 \text { HUF })\end{array}$ \\
\hline $\begin{array}{l}\text { Carer's allowance provided } \\
\text { by local governments }\end{array}$ & 799,494 & 0 & 0 & $-799,494$ \\
\hline $\begin{array}{l}\text { Public medicine service } \\
\text { provided by local } \\
\text { governments }\end{array}$ & 404,017 & 0 & 0 & $-404,017$ \\
\hline $\begin{array}{l}\text { Housing costs support in } \\
\text { cash }\end{array}$ & $5,981,980$ & $1,448,596$ & 0 & $-5,981,980$ \\
\hline Debt management service & 474,064 & 45,851 & 0 & $-474,064$ \\
\hline $\begin{array}{l}\text { Housing costs support in } \\
\text { kind }\end{array}$ & $1,441,753$ & 0 & 0 & $-1,441,753$ \\
\hline $\begin{array}{l}\text { Debt management - prepaid } \\
\text { consumption meter }\end{array}$ & 16,751 & 0 & 0 & $-16,751$ \\
\hline Municipal aid in cash & $2,924,835$ & 0 & 0 & $-2,924,835$ \\
\hline Municipal aid in kind & 849,822 & 0 & 0 & $-849,822$ \\
\hline $\begin{array}{l}\text { Other benefits regulated by } \\
\text { local decree }\end{array}$ & $3,621,064$ & $5,010,651$ & $5,480,761$ & $1,859,697$ \\
\hline $\begin{array}{l}\text { Other benefits provided by } \\
\text { local governments at its } \\
\text { discretion (in cash) }\end{array}$ & $3,327,961$ & $6,868,697$ & $5,291,112$ & $1,963,151$ \\
\hline
\end{tabular}


I. Hoffman \& A. Szatmári: The Transformation of the Municipal Social Benefit System in Hungary in the Last Decade

\begin{tabular}{|l|r|r|r|r|}
\hline $\begin{array}{l}\text { Other benefits provided by } \\
\text { local governments at its } \\
\text { discretion (in kind) }\end{array}$ & $4,262,492$ & 0 & 0 & $-4,262,492$ \\
\hline Municipal support & $5,636,253$ & $15,721,690$ & $17,715,888$ & $12,079,635$ \\
\hline Other & 697,657 & $1,753,068$ & $1,651,475$ & 953,818 \\
\hline Benefits examined in sum & $\mathbf{3 0 , 4 3 8 , 1 4 3}$ & $\mathbf{3 0 , 8 4 8 , 5 5 2}$ & $\mathbf{3 0 , 1 3 9 , 2 3 6}$ & $\mathbf{- 2 9 8 , 9 0 7}$ \\
\hline Abolished benefits in sum & $12,892,716$ & $1,494,447$ & 0 & $-12,892,716$ \\
\hline Existing benefits in sum & $17,545,427$ & $29,354,106$ & $30,139,236$ & $12,593,809$ \\
\hline
\end{tabular}

Table 3 shows the expenditures of local governments on the benefits selected for examination in 2015, 2016 and 2017. As it is shown, benefits comparable has declined slightly at national level between 2015 and 2017. Local governments spent 30.438 million HUF in 2015, 30.849 million HUF in 2016, and 30.139 million HUF in 2017. The abolished types of benefits (carer's allowance provided by local governments, public medicine service provided by local governments, housing costs support in cash and in kind, debt management and municipal aid in cash and in kind) was 12.893 million HUF in 2015. Benefits still existing (other benefits regulated by local decree or provided by local government at its discretion, the new municipal support and other not defined forms of benefits) increased from 17.545 million HUF to 30.139 HUF. Thus, we can say that the lack of abolished types of benefits has been almost counterbalanced by the increase of other - still existing types of benefits, at national level.

\subsubsection{Territorial differences}

The aim of further investigation is to find out that what the impact of changes was on the data at territorial level, since the abolished benefits were financed proportionally by the central budget (90 per cent) while the distribution of present central resources has a new method.

The territorial analysis requires the tackling of the differences in population number among municipalities. As we do not have any data about the recipients of the municipal benefits, we have divided the expenditure data with the number of residents on 1 January 2016 in each year. The social benefits per residents (inhabitants) depends, firstly, on the number of beneficiaries (which is an indicator of the social and economic situation of the population), and, secondly, on the amount provided per person (which is rather an indicator of the financial capacity of the municipality). Consequently, the higher amount per inhabitants is more probable on the territories where are more people in need who have obtained eligibility to the benefits, and, on the other hand, where the municipality has more resources to this aim. These two aspects are in controversy, because the municipality can reach higher tax revenues when the residents have higher income. 
Until the amendment of 2015, the housing benefits were regulated centrally in respect both of the eligibility criteria and of the amount obtainable by recipients. For this reason, the expenditure was more or less proportional to the economic situation of the people living in the area, and did not depend on the resources available to the municipality. Thus, we can say that the amount of housing benefits per person may be an appropriate indicator of the income position of the population of a territory (city, village or district, or county). However, municipalities had empowerment to complement the eligibility criteria with a further aspect, requesting the recipients to maintain their home in order. Despite this fact, and because of the central financing of the housing benefits, we can use the data relating to housing benefits per residents to show the territorial differences in the social and economic position of municipalities.

Our hypothesis is that since the amendments of 2015, the expenditure has depended rather on the available municipal resources coming from local tax revenue and from the central budget, and not on the number of inhabitants in need, because it is at local discretion to define the eligibility criteria, as well as the amount of benefits for all local social supports.

Table 4: Average social benefits examined per inhabitants per year in counties of Hungary in 2015, 2016 and 2017

\begin{tabular}{|l|l|l|l|}
\hline \multirow{2}{*}{ County } & \multicolumn{3}{|c|}{$\begin{array}{c}\text { Average local social benefits per } \\
\text { inhabitants (HUF) }\end{array}$} \\
\cline { 2 - 4 } & $\mathbf{2 0 1 5}$ & $\mathbf{2 0 1 6}$ & $\mathbf{2 0 1 7}$ \\
\hline BKK & 2,506 & 2,394 & 2,202 \\
\hline BAR & 4,338 & 3,896 & 3,775 \\
\hline BEK & 2,912 & 3,220 & 3,188 \\
\hline BAZ & 5,777 & 5,629 & 5,966 \\
\hline CSO & 2,253 & 2,639 & 2,776 \\
\hline FEJ & 1,853 & 2,006 & 1,978 \\
\hline FOV & 2,375 & 2,359 & 2,250 \\
\hline GYS & 1,715 & 2,070 & 2,134 \\
\hline HAB & 4,042 & 3,570 & 3,291 \\
\hline HEV & 3,847 & 3,959 & 3,885 \\
\hline JNK & 2,927 & 3,341 & 3,174 \\
\hline KEM & 1,641 & 1,820 & 1,760 \\
\hline NOG & 4,602 & 4,586 & 4,215 \\
\hline
\end{tabular}


I. Hoffman \& A. Szatmári: The Transformation of the Municipal Social Benefit System in Hungary in the Last Decade

\begin{tabular}{|l|l|l|l|}
\hline PES & 1,932 & 2,151 & 2,081 \\
\hline SOM & 4,735 & 4,440 & 4,597 \\
\hline SZB & 6,365 & 6,395 & 5,924 \\
\hline TOL & 3,620 & 3,186 & 3,049 \\
\hline VAS & 1,960 & 2,417 & 2,629 \\
\hline VES & 2,442 & 2,638 & 2,413 \\
\hline ZAL & 2,850 & 2,928 & 2,926 \\
\hline Country average & $\mathbf{3 , 1 0 3}$ & $\mathbf{3 , 1 4 5}$ & $\mathbf{3 , 0 7 3}$ \\
\hline
\end{tabular}

Source: Registers of the Hungarian State Treasury, edited by authors

Table 4 shows the average social benefits examined per inhabitants per year in the counties of Hungary in 2015, 2016 and 2017. In 2015, the municipal benefits per inhabitants were 3103 HUF per year in the country, varying between 1715 and 6365 HUF across counties. The highest amount was almost fourth more than the lowest. In 2017, the country average was almost the same (3073 HUF) while the range became narrower (between 1760 and 5966 HUF per inhabitants per year). The ratio between the highest and lowest amount decreased to 3.4. At the same time, we can observe that in counties with a higher level of benefits in 2015, the local benefits per inhabitants have generally declined but they have risen in counties with lower level of benefits. In view of the above-mentioned fact that in 2015 the amount depended rather on the inhabitants' situation, we can say that the main effect of the amendment is a kind of "convergence" among the counties. However, what would be desirable concerning the territorial social differences is not the convergence of the amount spent but that of the level of living standard, which requires more support for disadvantaged regions and less for the rest. The change of municipal benefits across counties is demonstrated in Figure 2. 
I. Hoffman \& A. Szatmári: The Transformation of the Municipal Social Benefit System in Hungary in the Last Decade

Figure 2: Change of average local social benefits per inhabitants in the counties of Hungary

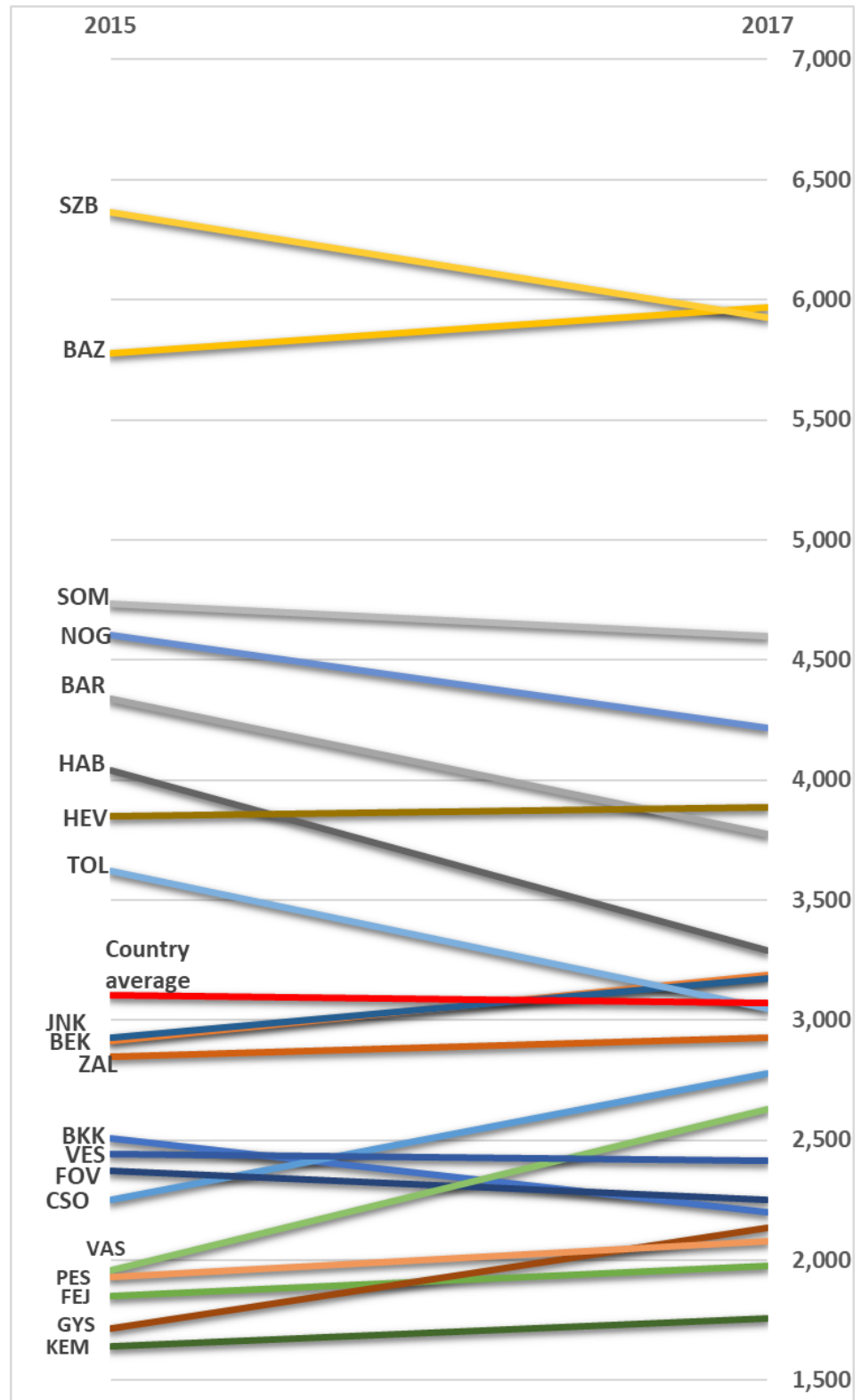

Source: Registers of the Hungarian State Treasury, edited by authors 
In 2015, the 3053 examined municipalities spent 7.91 billion HUF (ca. 25,6 million EUR) as a whole on housing benefits regulated centrally. These benefits reached only 807 HUF per inhabitants per year at national level while the average indicator has shown a wide variation across the country. There were 460 municipalities which did not provide inhabitants with housing benefits at all. The higher amount per inhabitants reached 25.763 HUF in a village of Baranya county, Siklós district. There were merely 35 municipalities where the amount of housing benefits per inhabitants was higher than 10.000 HUF. It is worth examining how the examined benefits have been changed after the amendment in these villages, whether they could maintain the relatively high level of supports or not.

According to the data available, the 35 municipalities spent 334.4 million HUF on the examined benefits in 2015. The housing benefits represented 36 per cent of the whole expenditure (120.4 million HUF). The examined benefits decreased to 239.6 million HUF in 2017, which means that they could not replace the housing benefits centrally financed and regulated by supports provided at their own regulation and resources. The examined benefits dropped from 20.873 HUF to 14.956 HUF per inhabitants per year (minus 28,4 per cent).

At the same time, at the other end of the scale, the 460 municipalities without any housing benefits in 2015 (despite the central regulation and financing) spent only 2.175 HUF per inhabitants in that year as a whole, and were able to increase this amount to 2.846 HUF (plus 30.9 per cent).

\section{6}

\section{Conclusions}

Different municipal social benefit systems have evolved in Europe. These models are influenced by the welfare system and by the municipal regulation of the given country. It is a common element, that the additional income benefits are primarily provided by the local governments but the role of the central government is more significant in the field of the income replacement benefits.

The transformations of the Hungarian municipal social benefit system have been influenced by these models and their changes. After the Democratic Transition a first tier based, decentralised and fragmented municipal social benefit model evolved in Hungary. During the 1990s and in 2000s the fragmented system was centralised: the role of the central government was strengthened and the common standard of the municipal benefits was established by the amendments of the Szt. Since the transformation of the Hungarian local self-government system the municipal social benefit model has been changed, as well. The income replacement benefits have been centralised. The aim of the reform was to strengthen the accessibility to these benefits. A reverse process can be observed in the field of the additional income benefits: a new, fragmented system has evolved since 2015. 
The impact of the reform has been analysed in our article. It is clear, that the accessibility to the income replacement benefits has not been changed significantly, the former model which was based on the delegated state task provision of the municipal clerks was a satisfying solution. The decentralisation of the additional income benefits resulted in other changes; the gap between the different municipalities has increased, especially in the field of the housing benefits. Thus, the aim of the legislator has been fulfilled partly: the differences between the different municipalities has become more significant.

\section{Acknowledgements}

This article was supported by the János Bolyai Research Scholarship of the Hungarian Academy of Sciences.

\footnotetext{
Notes:

1 The local regulative powers were limited. Although they could define the concept of "orderly residential environment" but the scope of the concept was limited to those rules which were not regulated by the laws on construction law. Similarly, the quality of the apartment and its equipment could not be part of the definition of the concept. These limitations on the regulation were emphasised by the Curia (the Supreme Court of Hungary)., especially in the Resolution No. Köf.5.051/2012/6.

2 The name of the heading is the translation of the official definition, but, regarding the breakdown, this is not a correct name. Several benefits in kind are also included in this category.
} 


\section{References:}

Alcock, P. \& May, M. (2003) Social Policy in Britain (Basingstoke - New York: Palgrave Macmillan)

Esping-Andersen, G (2002) Towards the Good Society, Once Again?, In: Esping-Andersen, G., Gallie, D., Hemerijck A. \& Myles, J. (eds.) Why We Need a New Welfare State (Oxford: Oxford University Press), pp. 2-25.

ESPROSS (2018) European System of Integrated Social Protection Statistics, available at: http://appsso.eurostat.ec.europa.eu/nui/submitViewTableAction.do (December 21, 2018).

Fazekas, M. (1999) A szociális igazgatás, In: Ficzere, L. \& Forgács, I. (eds.) Magyar közigazgatási jog. Különös rész európai uniós kitekintéssel. (Budapest: Osiris), pp. 181209.

Fazekas, M. (2005) A szociális igazgatás, In: Ficzere, L. \& Forgács, I. (eds.) Magyar közigazgatási jog. Különös rész európai uniós kitekintéssel. (Budapest: Osiris), pp. 280305 .

Ferge, Zs. (2017) Magyar társadalom-és szociálpolitika. (Budapest, Osiris).

Hill, M. \& Irving, Z. M. (2009) Understanding Social Policy. (Chichester: Wiley and Blackwell).

Hoffman, I. (2016) Bevezetés a szociális jogba. (Budapest: ELTE Eötvös Kiadó).

Hoffman, I. (2018) Challenges of Implementation of the European Charter of Local SelfGovernment in the Hungarian Legislation, Lex localis - Journal of Local SelfGovernment, 16(4), pp. 929-938.

Hoffman, I. \& Krémer, B. (2005) Amit a SZOLID Projekt mutat, Esély,16(3), pp. 29-63.

Horáková, M., Horák, P., Hora, O. \& Sirovátka, T. (2014) Governance, Finance and Employment in Social Services in the United Kingdom, In: Sirovátka, T. \& Greve, B. (eds.) Innovation in Social Services. (Farnham - Burlington: Ashgate), pp. 123-142.

Hungler, S. (2012) The Poor, the Unemployed and the Public Worker - a Comparative Essay on National Unemployment Policies Contribution to Deepening Poverty, International and Comparative Law Review 12(1), pp. 117-134.

Jakab, N. (2013) Közfoglalkoztatás, In: Jakab, N., Prugberger, T. \& Rácz, Z. (eds.) Szociális jog I. Európai és Magyar foglalkoztatás támogatási és munkaügyi-, valamint munkavédelmi igazgatási jog (Miskolc: Bíbor Kiadó).

Kornai, J. (1992) The Socialist System (Princeton: Princeton University Press).

Krémer, B. (2009) Szociálpolitika (Budapest: Napvilág Kiadó).

Mózer, P., Tausz, K. \& Varga, A. (2015) A segélyezési rendszer változásai, Esély, 25(3), pp. 43-66.

Nagy, M. \& Hoffman, I. (eds.) (2014) A Magyarország helyi önkormányzatairól szóló törvény magyarázata (Budapest: HVG-Orac)

Lehto, J., Moss, N. \& Rostgaard, T. (1999) Universal public social care and health services?, In: Kautto, M., Heikkilä, M., Hvinden, B., Marklund, S. \& Ploug, N. (eds.) Nordic social policy. Changing welfare states (London \& New York: Routledge), pp. 104-132.

Palier, B. \& Marin, C. (2008) Reforming the Bismarckian Welfare Systems (Malden: Blackwell Publishing).

Rauch, D. (2008) Central versus local service regulation: accounting for diverging old-age care developments in Sweden and Denmark, 1980-2000, Social Policy and Administration, 42(3), pp. 267-287.

Szatmári, A. (2018) Ki a rászoruló?, Jogi tanulmányok, 19(1), pp. 318-330. 
Tausz, K. (2017) Segélyezés. In: Ferge Zs.: Magyar társadalom- és szociálpolitika (Budapest, Osiris), pp. 310-337.

Waltermann, E. (2011) Sozialrecht. (Heidelberg: C. F. Müller) 